\title{
Pesticides in Ground Water - Teton County, Wyoming, 2001-02
}

In 1991, members of local, State, and Federal governments, as well as industry and interest groups, formed the Ground-water and Pesticide Strategy Committee to prepare the State of Wyoming's generic Management Plan for Pesticides in Ground Water. Part of this management plan is to sample and analyze Wyoming's ground water for pesticides. In 1995, the U.S. Geological Survey, in cooperation with the Ground-water and Pesticide Strategy Committee, began statewide implementation of the sampling component of the State of Wyoming's generic Management Plan for Pesticides in Ground Water. During 2001-02, baseline monitoring was conducted in Teton County.

\section{PESTICIDES IN GROUND WATER}

Synthetic organic pesticides are used to control weeds, insects, and other organisms in a wide variety of agricultural and nonagricultural settings. The use of pesticides has helped to make the United States the world's largest producer of food (Barbash and Resek, 1996). Pesticide use, however, has also been accompanied by concerns about potential adverse effects on the environment and human health. A potential pathway for the transport of pesticides is through hydrologic systems, which supply water for both humans and natural ecosystems. Water is one of the primary ways pesticides are transported from an application area to other locations

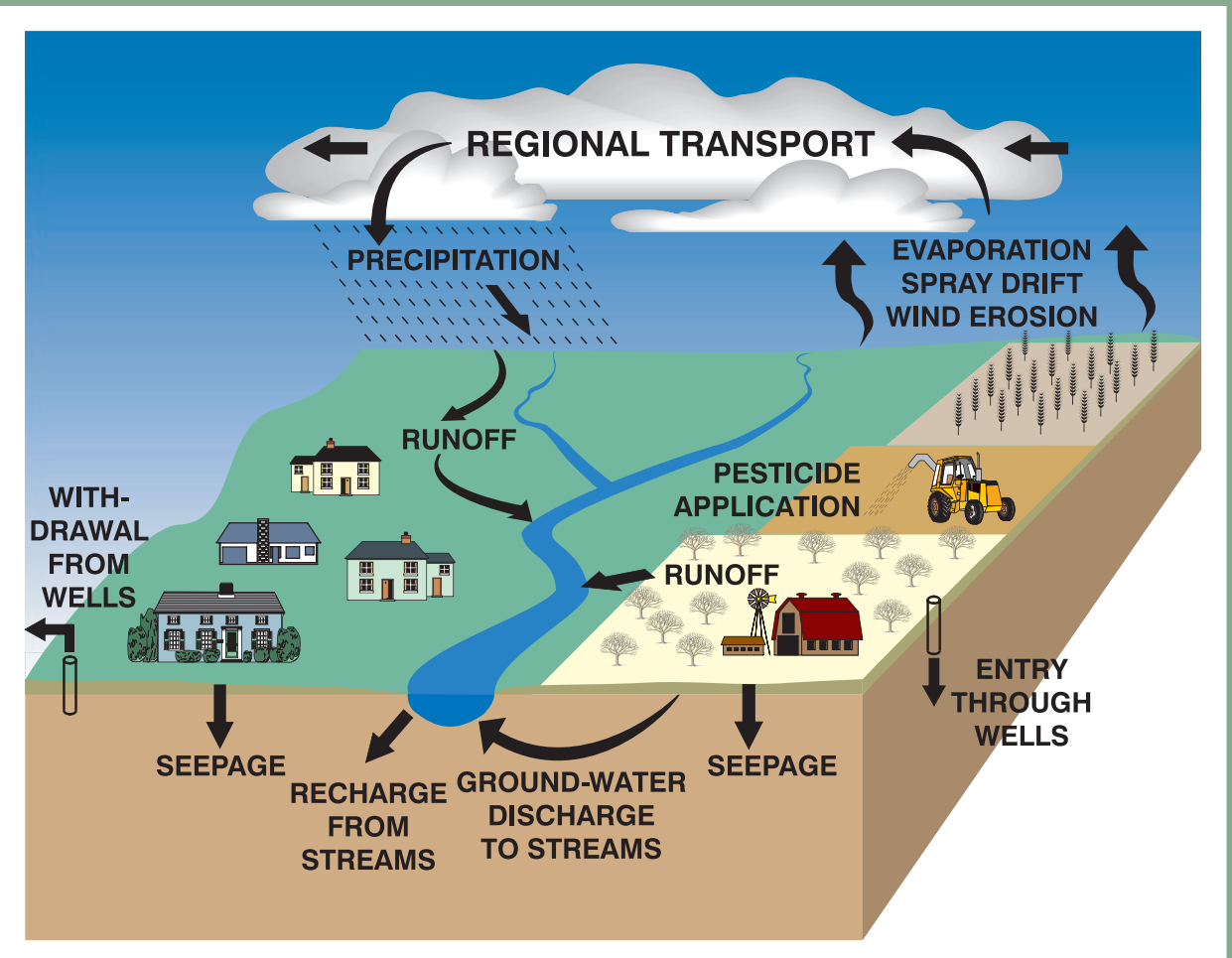

Figure 1. Pathways of pesticide movement in the hydrologic cycle (modified from Barbash and Resek, 1996). in the environment (fig. 1) (Barbash and Resek, 1996).

Pesticide contamination of ground water is a national issue because of the widespread use of pesticides, the expense and difficulty of remediating ground water, and the fact that ground water is used for drinking water by about 50 percent of the Nation's population. Although application rates and the variety of pesticides used may be greater in urban areas, concern over their presence in ground water is especially acute in rural agricultural areas where more than 95 percent of the population rely upon this resource for drinking water (Solley and others, 1998).

\section{WYOMING'S PESTICIDE MANAGEMENT PLAN}

The Ground-water and Pesticide Strategy Committee (GPSC) has developed the generic State Management Plan for Pesticides in Ground Water for the State of Wyoming (SMP) (Wyoming Groundwater and Pesticides Strategy Committee, 1999). Wyoming was required by the U.S. Environmental Protection Agency to have developed an SMP in order for individuals and organizations to continue using certain pesticides in the state. The SMP includes information relating to individuals and organizations involved with implementation of the SMP, methods of preventing ground-water contamination, ground-water 
Table 1. Baseline monitoring for pesticides in Teton County, late summer/fall 2001 and spring 2002.

[ $\mu \mathrm{g} / \mathrm{L}$, micrograms per liter; $\mathrm{C}$, estimated values used in calculation]

\begin{tabular}{|c|c|c|c|c|c|c|}
\hline Pesticide & $\begin{array}{l}\text { Pesticide } \\
\text { trade name }\end{array}$ & Pesticide action ${ }^{1}$ & $\begin{array}{l}\text { Number of } \\
\text { detections/ } \\
\text { number of } \\
\text { samples }^{2}\end{array}$ & $\begin{array}{c}\text { Maximum } \\
\text { concentration } \\
(\mu \mathrm{g} / \mathrm{L})\end{array}$ & $\begin{array}{c}\text { Average } \\
\text { concentration } \\
\text { of detections } \\
(\mu \mathrm{g} / \mathrm{L})\end{array}$ & $\begin{array}{c}\text { Safe drinking } \\
\text { water } \\
\text { standard } \\
(\mu \mathrm{g} / \mathrm{L})\end{array}$ \\
\hline \multicolumn{7}{|c|}{ Non-focal pesticides detected in Teton County ground water } \\
\hline Prometon & Pramitol & $\begin{array}{l}\text { Non-selective } \\
\text { herbicide }\end{array}$ & $5 / 24$ & 0.1 & $0.04 \mathrm{C}$ & ${ }^{3} 100$ \\
\hline \multicolumn{7}{|c|}{ Focal pesticides not detected in Teton County ground water } \\
\hline 2,4-D & Aldicarb Sulfone ${ }^{4}$ & Bromacil & DCPA & Metalachlor & Simazine & \\
\hline Alachlor & Aldicarb Sulfoxide ${ }^{4}$ & Clopyralid & Dicamba & Metribuzin & Tebuthiuron & \\
\hline Aldicarb & Atrazine & Cyanazine & Hexazinone & Picloram & Telone & \\
\hline \multicolumn{7}{|c|}{ Focal pesticides not analyzed in Teton County ground water (no method of analysis available) } \\
\hline \multicolumn{7}{|c|}{ Difenzoquat } \\
\hline
\end{tabular}

${ }^{1}$ Meister (1996)

${ }^{2}$ Each of the 12 sites was sampled twice. One site located in Jackson had no water in the well during the spring sampling, and an adjacent well was used for that site.
${ }^{3}$ U.S. Environmental Protection Agency Lifetime Health Advisory Level (U.S. Environmental Protection Agency, 2002).

${ }^{4}$ Degradation product of aldicarb. monitoring, and the responses required if pesticides are detected in ground water.

One critical part of the SMP is groundwater monitoring. This ground-water monitoring program has two phases. The first phase, baseline monitoring, is designed to determine what pesticides, if any, have leached into the county's ground water. The second phase, problem identification monitoring, is used to gather additional information about the ground water near wells having significant pesticide detections.

Baseline monitoring is prioritized by a county rank and the vulnerability of the county's ground water to pesticides. During development of the SMP, the GPSC evaluated each county in Wyoming to determine the potential vulnerability of the county's ground water to pesticides. Each county was ranked according to the extent of cropland and urban areas in the county, and the amount of pesticides sold within the county in 1991 (Wyoming Groundwater and Pesticides Strategy Committee, 1999).

A ground-water vulnerability map was prepared for the uppermost or shallowest aquifer (Hammerlink and Arneson, 1998). A Geographic Information System was used to overlay seven layers describing hydrogeology and land use. Ground water is more vulnerable because of either inherent sensitivity of the hydrogeology, or because of the combination of the sensitivity and associated land use. The map was used to assist in the selection of monitoring sites in each county. Monitoring focuses on areas where the ground water is most vulnerable.

The GPSC selected 18 pesticides (focal pesticides) and 2 degradation products to be sampled as part of the SMP (table 1). The analytical method used to detect the focal pesticides can also detect 66 other pesticides and degradation products. Any additional pesticides detected are listed in table 1 as non-focal pesticides. Ground water from all wells in the baseline monitoring program was analyzed for the pesticides listed in table 1, with the exception of difenzoquat and metsulfuron, for which analytical methods were not available.

The goal of the ground-water sampling part of the SMP is to collect ground-water samples for pesticide analyses in all 23 Wyoming counties. To date, sampling has been completed in Goshen (1995-96), Park (1997), Washakie (1997-98), Fremont (1998-99), Lincoln (1998-99), Laramie (1998-99), Big Horn (1999-2000), Sheridan (1999-2000), Platte (2000-01), Johnson (2000-01), Crook (2000-01), Natrona (2001-02), Sweetwater (2001-02), Teton (2001-02), and Uinta (2002-03) Counties. Sampling began in 2003 in Albany, Converse, and Hot Springs Counties.

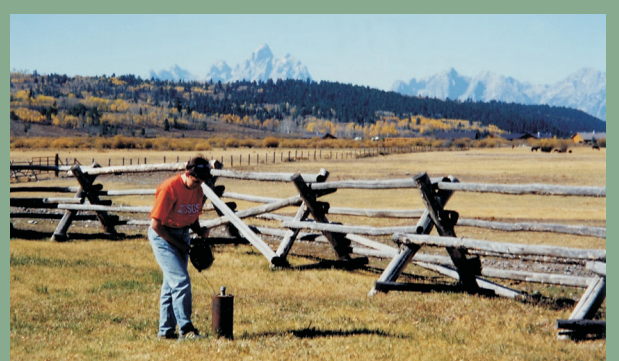

\section{GROUND-WATER MONITORING IN} TETON COUNTY

Ground water in Teton County was ranked fifteenth most vulnerable to pesticide contamination in Wyoming (Wyoming Ground-water and Pesticide Strategy Committee, 1999). The vulnerability map created by the Spatial Data and Visualization Center (Hammerlink and Arneson, 1998) identifies ground water found in unconsolidated Quaternary deposits (primarily alluvial and terrace deposits) and the mountainous areas throughout the county most vulnerable to pesticides (shown as red or yellow on fig. 2). The mountainous areas were not sampled, because although the hydrogeology makes the ground water susceptible to contamination, land use does not create a large potential for contamination and because sampling locations were not available in these areas.

Twelve sites were selected in Teton County (fig. 3) for baseline monitoring. All sites were located in Snake River or Buffalo Fork alluvium. All sites were sampled in late summer or fall 2001 and spring 2002.

None of the 18 focal pesticides was detected in Teton County (table 1). One non-focal pesticide was detected in 3 of 12 sites sampled in Teton County; the concentrations were less than $1 / 1000$ of the applicable drinking-water standard (U.S. Environmental Protection Agency, 2002) (table 1). 


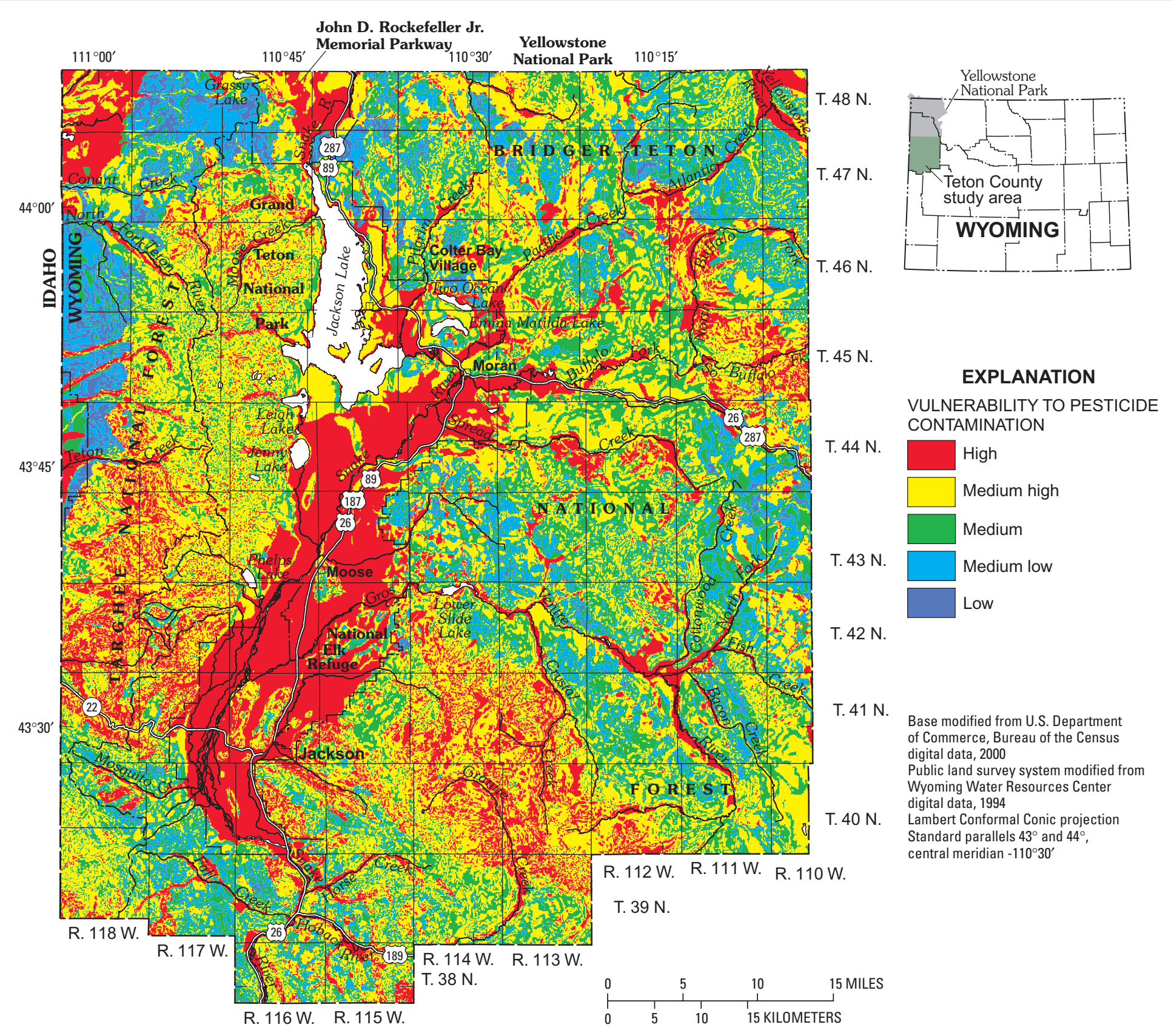

Figure 2. Vulnerability of Teton County ground water to pesticide contamination (from Hammerlink and Arneson, 1998).

The only detected pesticide in Teton County was prometon (detected in 5 out of 24 samples). Prometon is the active ingredient in Pramitol, a general-use pesticide, and its detection is typically associated with urban land use (Barbash and others, 1999). Prometon was also the most commonly detected pesticide in Sheridan, Crook, Johnson, and Natrona Counties.

\section{DATA DISTRIBUTION AND AVAILABILITY}

The sampling results have been provided to local groups interested in pesticides in ground water in Teton County. The information can be used by citizens and local governments to help understand current conditions. Analytical results of the Teton County sampling can be found in Swanson and others (2002) and Swanson and others (2003), or on the internet at http://waterdata.usgs.gov/wy/nwis/qwdata. Analytical results and fact sheets for all counties sampled to date are available from the U.S. Geological Survey in Cheyenne by phone, email, and on the internet at http://wy.water.usgs.gov/projects/ pesticidel.

\section{REFERENCES}

Barbash, J.E., and Resek, E.A., 1996, Pesticides in ground water: Distribution, trends, and governing factors, in Gilliom, R.J., ed., Pesticides in the hydrologic system (v. 2): Lewis Publishing, 590 p.
Barbash, J.E., Thelin, G.P., Kolpin, D.W., and Gilliom, R.J., 1999, Distribution of major herbicides in ground water of the United States: U.S. Geological Survey WaterResources Investigations Report 98-4245, $64 \mathrm{p}$.

Hammerlink, J.D., and Arneson, C.S., editors, 1998, Wyoming ground water vulnerability assessment handbook: Volume 2. Assessing ground water vulnerability to pesticides: University of Wyoming, Laramie, Spatial Data and Visualization Center Publication SDVC 98-01-2, variable pagination.

Meister, R.T., 1996, Farm Chemicals Handbook: Willoughby, Ohio, Meister Publishing Co., variable pagination.

Solley, W.B., Pierce, R.R., and Perlman, H.A. 1998, Estimated use of water in the United 


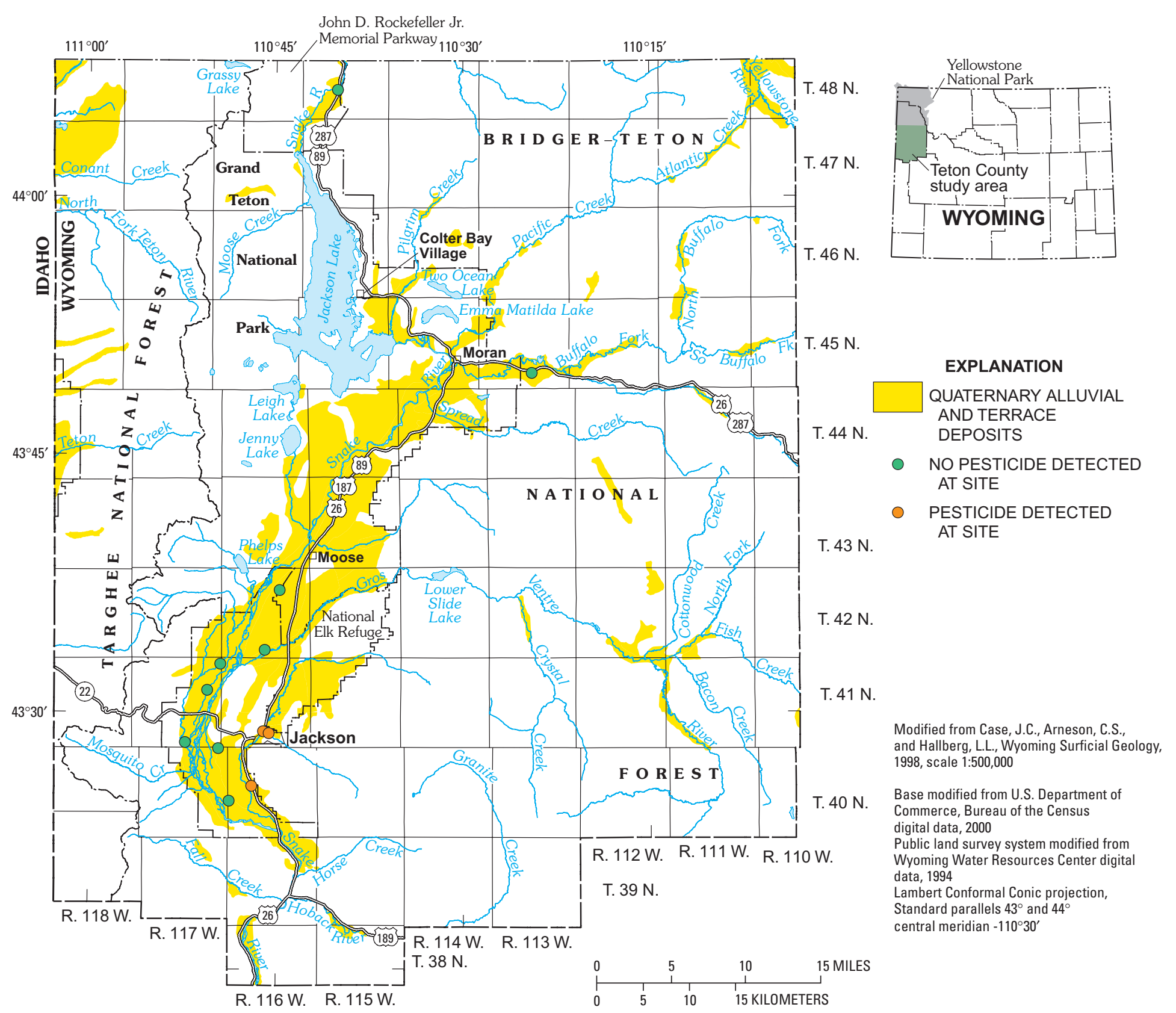

Figure 3. Location of wells sampled in Teton County, Wyoming, and notation of pesticide detection in each well.

States in 1995: U.S. Geological Survey Circular 1200, $71 \mathrm{p}$.

Swanson, R.B., Blajszczak, E.J., Roberts, S.C., Watson, K.R., and Mason, J.P., 2002, Waterresources data, Wyoming, water year 2001, Volume 2. Ground Water: U.S. Geological Survey Water-Data Report WY-01-2, 127 p.

Swanson, R.B., Blajszczak, E.J., Roberts, S.C., Watson, K.R., and Mason, J.P., 2003, Waterresources data, Wyoming, water year 2002, Volume 2. Ground Water: U.S. Geological Survey Water-Data Report WY-02-2, 140 p.

U.S. Environmental Protection Agency, 2002, Drinking water regulations and health advisories: EPA 822-R-02-038.

Wyoming Ground-water and Pesticides Strategy Committee, 1999, Wyoming generic state management plan for pesticides and ground water: prepared for Wyoming Department of Agriculture, Cheyenne, Wyoming, $103 \mathrm{p}$.

- Prepared by Cheryl A. Eddy-Miller and Kendra J. Remley

- Layout prepared by Suzanne C. Roberts

This document was prepared by the U.S. Geological Survey (USGS), the Wyoming Department of Agriculture (WDA), and the Wyoming Department of Environmental Quality, Water Quality Division (WDEQ). All agencies are members of the Ground-water and Pesticide Strategy Committee.

This project has been funded in part with a Section 319 grant from the U.S. Environmental Protection Agency to Wyoming Department of Environmental Quality's Non-Point Source Program.

The use of trade, product, industry, or firm names is for descriptive purposes only and does not imply endorsement by the U.S. Government.
FOR MORE INFORMATION, CONTACT:

Wyoming Department of Agriculture 2219 Carey Avenue

Cheyenne, Wyoming 82002

(307) 777-7324

Kevin Frederick

Wyoming Department of Environmental Quality,

Water Quality Division 4th Floor, Herschler Building Cheyenne, Wyoming 82002

(307) 777-7781

\section{Cheryl Eddy Miller}

U.S. Geological Survey, WRD 2617 E. Lincolnway, Suite B Cheyenne, Wyoming 82001 (307) 778-2931

Email: cemiller@usgs.gov 